\title{
PENGARUH BEBAN LALU LINTAS TERHADAP UMUR PERKERASAN JALAN RIGID
}

\author{
Ir. Santausa Purnama, MM \\ Dosen STTD \\ Jl. Raya Setu No. 89, Bekasi \\ Telp./Fax : (021) 8254640
}

\section{Sumantri W Praja, M.Sc \\ Dosen STTD}

Jl. Raya Setu No. 89, Bekasi

Telp./Fax : (021) 8254640

\author{
Budiharso Hidayat, ATD, MT \\ Dosen STTD \\ Jl. Raya Setu No. 89, Bekasi \\ Telp./Fax : (021) 8254640
}

\author{
Novita Sari, M.Eng \\ Dosen STTD \\ Jl. Raya Setu No. 89, Bekasi \\ Telp./Fax : (021) 8254640 \\ DR.Ir. Kusnendi S, MT \\ Dosen STTD \\ Jl. Raya Setu No. 89, Bekasi \\ Telp./Fax : (021) 8254640
}

\begin{abstract}
Road pavement is a mixture of aggregates and binding materials used to service traffic loads. While the binding material on road pavement commonly used in pavement planning includes cement and asphalt. Rigid Pavement is a type of pavement that is widely used in Indonesia, especially for roads that have high traffic volumes. Rigid pavement structure is designed to be able to receive traffic loads where the pavement must be guaranteed strength and thickness so as to be able to withstand the traffic load on it. In general, the age of road pavement is determined based on the cumulative number of standard vehicle trajectories CESA (Cummulative Equivalent Standard Axle) estimated to be through the pavement, calculated from the start the pavement is made and used until the pavement is categorized as damaged (depleted service value).
\end{abstract}

Keywords: Road Pavement, Traffic Load, Tie Material 


\begin{abstract}
ABSTRAKSI
Perkerasan jalan adalah campuran antara agregat dan bahan ikat yangdigunakan untuk melayani beban lalu lintas. Sedangkan bahan ikat pada perkerasan jalan yang biasa digunakan dalam perencanaan perkerasan jalan antara lain semen dan aspal. Perkerasan kaku atau Rigid Pavement adalah jenis perkerasan yang banyak digunakan di Negara Indonesia terutama jalan-jalan yang mempunyai volume lalu lintas yang tinggi. Struktur perkerasan kaku di desain untuk dapat menerima beban lalu lintas dimana perkerasan ini harus terjamin kekuatan dan ketebalannya sehingga mampu menahan beban lalu lintas yang ada diatasnya. Pada umumnya umur perkerasan jalan ditetapkan berdasarkan jumlah komulatif lintasan kendaraan standar CESA (Cummulative Equivalent Standar Axle) yang diperkirakan akan melalui perkerasan tersebut, diperhitungkan dari mulai perkerasan tersebut dibuat dan dipakai umum sampai dengan perkerasan tersebut dikategorikan rusak (habis nilai pelayanannya).
\end{abstract}

Kata Kunci : Perkerasan Jalan, Beban Lalu lintas, Bahan ikat

\title{
PENDAHULUAN
}

\section{Latar Belakang}

Jalan merupakan prasarana yang sangat dibutuhkan dalam sistem transportasi untuk menghubungkan suatu tempat ke tempat lain dalam rangka pemenuhan kebutuhan ekonomi, sosial, dan budaya. Kondisi jalan yang baik diperlukan untuk kelancaran kegiatan transportasi yaitu untuk mempercepat kelancaran mobilisasi barang atau jasa secara aman dan nyaman. Suatu perencanaan jalan diharapkan dapat memenuhi fungsi dasar jalan yaitu memberikan pelayanan yang optimal pada arus lalu lintas yang melaluinya.

Perkerasan jalan merupakan suatu komponen yang sangat penting dalam suatu pergerakan lalu lintas, kualitas jalan yang baik akan mendukung kelancaran lalu lintas orang dan barang pada suatu daerah. Perkerasan jalan adalah campuran antara agregat dan bahan ikat yangdigunakan untuk melayani beban lalu lintas. Agregat yang biasanya dipakai dalamperkerasan jalan adalah batu pecah (split) 
atau batu kali yang sudah memenuhi standar agregat yang ditetapkan dalam perencanaan perkerasan jalan. Sedangkan bahan ikat pada perkerasan jalan yang biasa digunakan dalam perencanaan perkerasan jalan antara lain semen dan aspal. Perkerasan kaku atau Rigid Pavement adalah jenis perkerasan yang banyak digunakan di Negara Indonesia terutama jalan-jalan yang mempunyai volume lalu lintas yang tinggi. Struktur perkerasan kaku di desain untuk dapat menerima beban lalu lintas dimana perkerasan ini harus terjamin kekuatan dan ketebalannya sehingga mampu menahan beban lalu lintas yang ada diatasnya.

\section{Perumusan Masalah}

Berdasarkan uraian di atas, maka dirumuskan masalah yang akan dibahas dalam penelitian ini, yaitu:

a. Berapa besar beban kendaraan pada suatu segmen jalan akibat dari volume lalu lintas?

b. Berapa besar kekuatan exsisting perkerasan jalan eksisting?

c. Berapa besar pengaruh beban lalu lintas terhadap umur rencana jalan?

\section{Tujuan Penelitian}

Tujuan dari penelitian ini adalah:

a. Mengetahui volume lalu lintas eksisting pada suatu segmen jalan.

b. Mengetahui beban lalu lintas eksisting pada suatu segmen jalan.

c. Mengetahui kekuatan eksisting perkerasan jalan pada suatu segmen jalan yang ditinjau.

d. Mengetahui pengaruh beban lalu lintas terhadap perkerasan jalan pada suatu segmen 


\section{Beban Lalu Lintas}

Berdasarkan standar perencanaan perkerasan beton semen (Pd-T-14-2003) Penentuan beban lalu-lintas rencana untuk perkerasan beton semen, dinyatakan dalam jumlah sumbu kendaraan niaga (commercial vehicle), sesuai dengan konfigurasi sumbu pada lajur rencana selama umur rencana. Lalu-lintas harus dianalisis berdasarkan hasil perhitungan volume lalu-lintas dan konfigurasi sumbu, menggunakan data terakhir atau data 2 tahun terakhir. Kendaraan yang ditinjau untuk perencanaan perkerasan beton semen adalah yang mempunyai berat total minimum 5 ton. Konfigurasi sumbu untuk perencanaan terdiri atas 4 jenis kelompok sumbu sebagai berikut :
a. Sumbu tunggal roda tunggal (STRT).
b. Sumbu tunggal roda ganda (STRG).
c. Sumbu tandem roda tunggal (STdRT).
d. Sumbu tridem roda ganda (STrRG).

Data lalu - lintas adalah data utama yang diperlukan untuk perencanaan teknik jalan, karena kapasitas jalan yang akan direncanakan tergantung dari komposisi lalu - lintas yang akan menggunakan jalan pada suatu segmen jalan yang ditinjau. Besarnya volume atau arus lalu - lintas diperlukan untuk mementukan jumlah dan lebar lajur pada satu jalur jalan dalam penentuan karakteristik geometri, sedangkan jenis kendaraan akan menentukan kelas beban atau MST (Muatan Sumbu Terberat) yang berpengaruh langsung pada perencanaan konstruksi perkerasan. Unsur lalu - lintas adalah benda atau pejalan kaki 


\section{Hasil Pengukuran Axle Load dengan Weight In Motion.}

a. Axle Load rata-rata moda truk sedang.

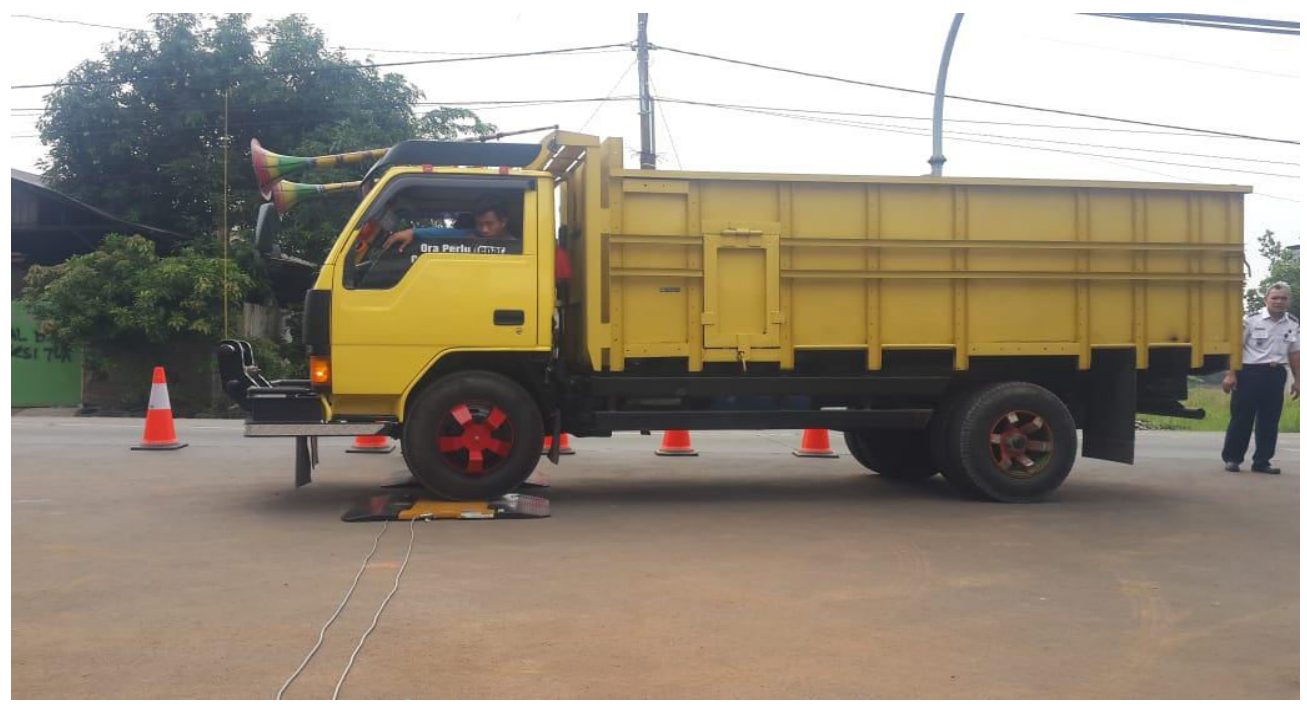
Roda Depan
$=1.190 \mathrm{Kg}$
Roda Belakang $\quad=1.200 \mathrm{Kg}$.
Total $=2.390 \mathrm{Kg}$.

b. Axle Load Rata-rata Moda Truk Kecil/ Pick Up.

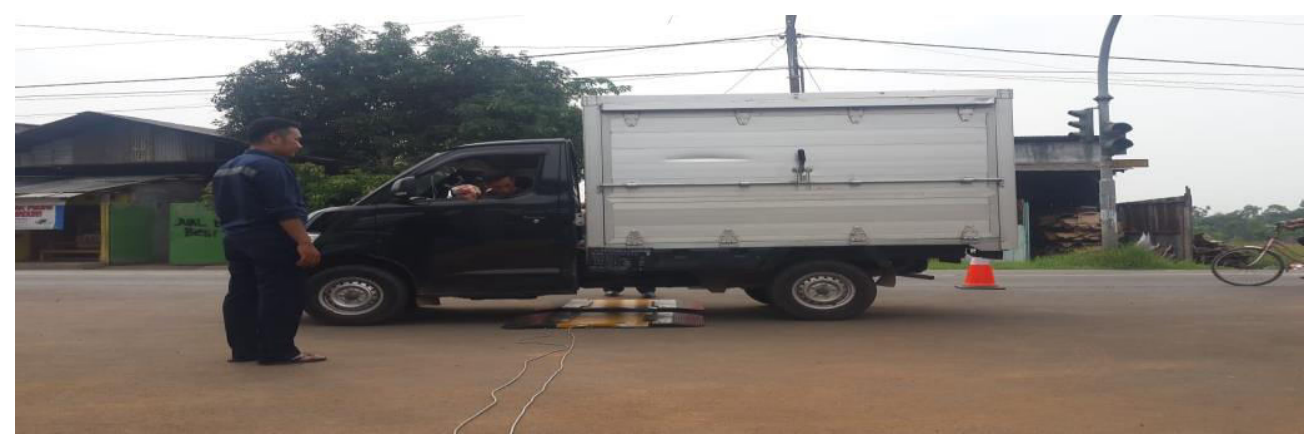

Roda Depan

Roda Belakang

Total

$$
\begin{array}{lr}
= & 940 \mathrm{Kg} \\
= & 840 \mathrm{Kg} . \\
= & 1.780 \mathrm{Kg} .
\end{array}
$$


c. Axle Load Rata-rata Moda Mobil Penumpang.

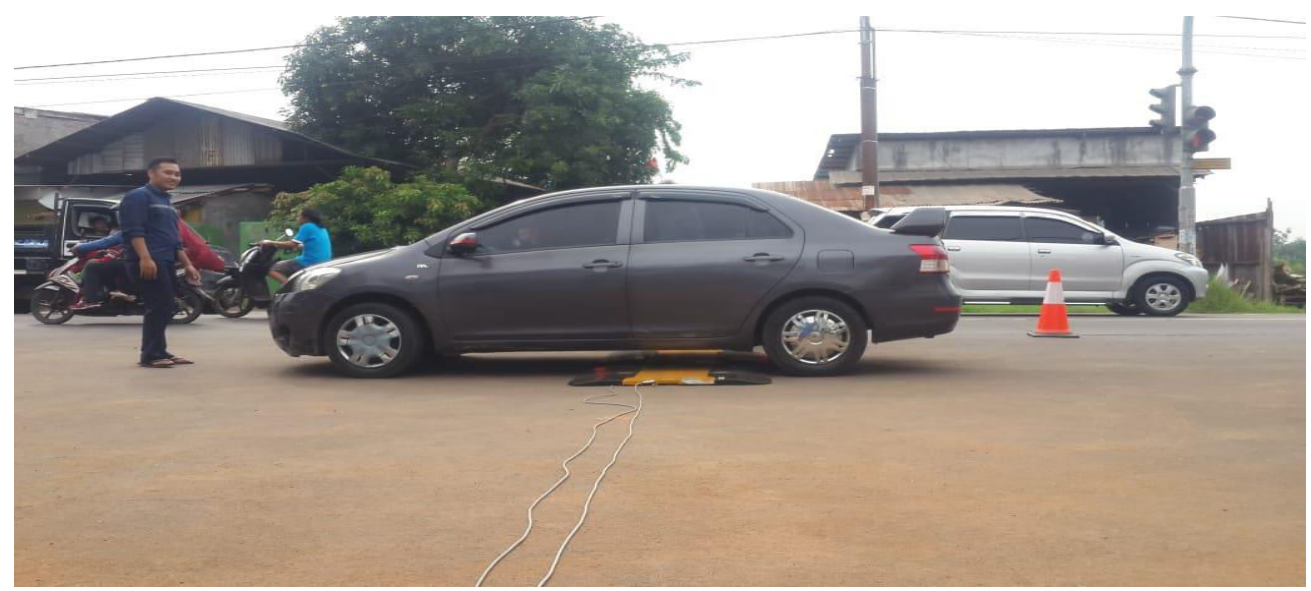

$\begin{array}{lll}\text { Roda Depan } & = & 370 \mathrm{Kg} \\ \text { Roda Belakang } & = & 420 \mathrm{Kg} . \\ \text { Total } & = & 790 \mathrm{Kg} .\end{array}$

d. Axle Load Rata-rata Moda Mobil Penumpang Umum.

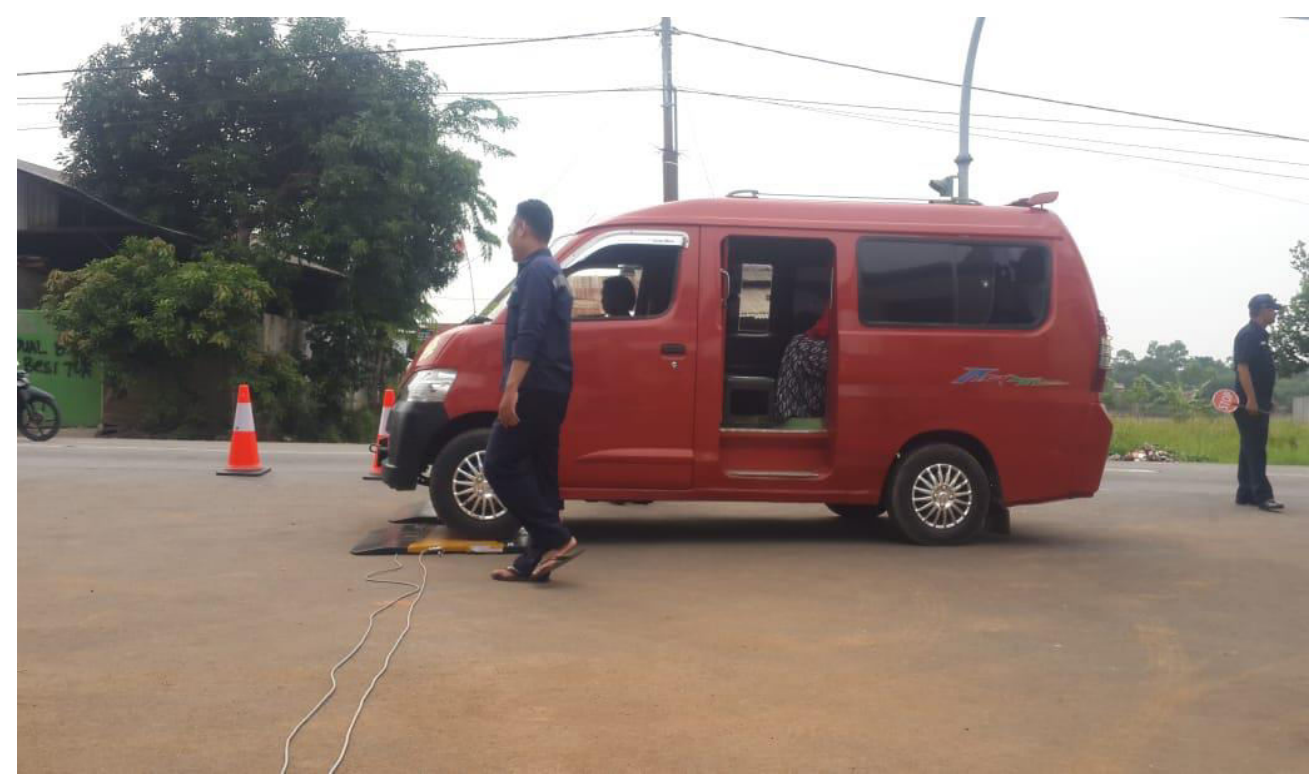
Roda Depan
$=\quad 800 \mathrm{Kg}$
Roda Belakang
$=680 \mathrm{Kg}$.
Total
$=1.480 \mathrm{Kg}$. 
e. Axle Load Rata-rata Moda Mobil Box (sedang).
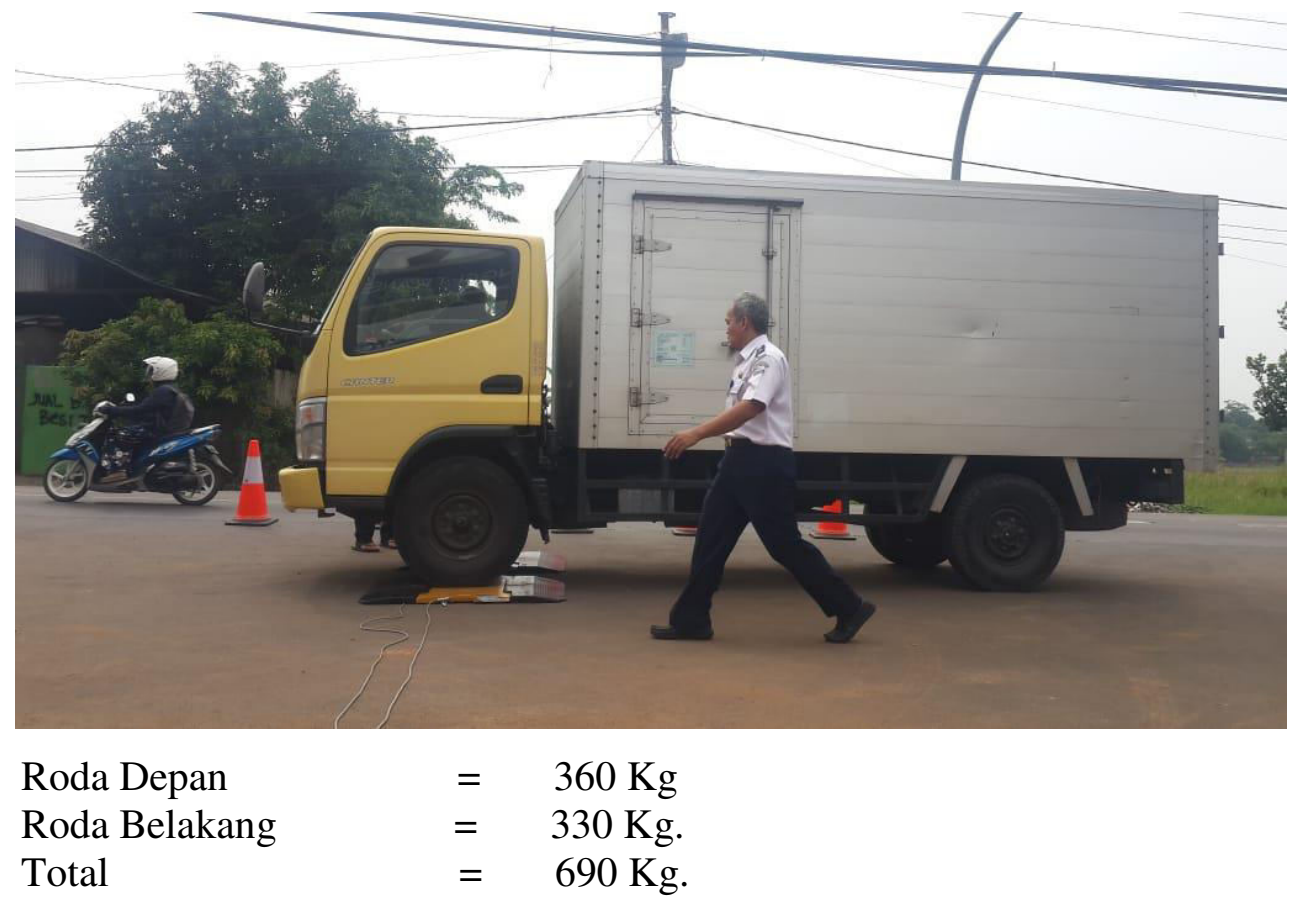

f. Axle Load Rata-rata Moda Sepeda Motor.

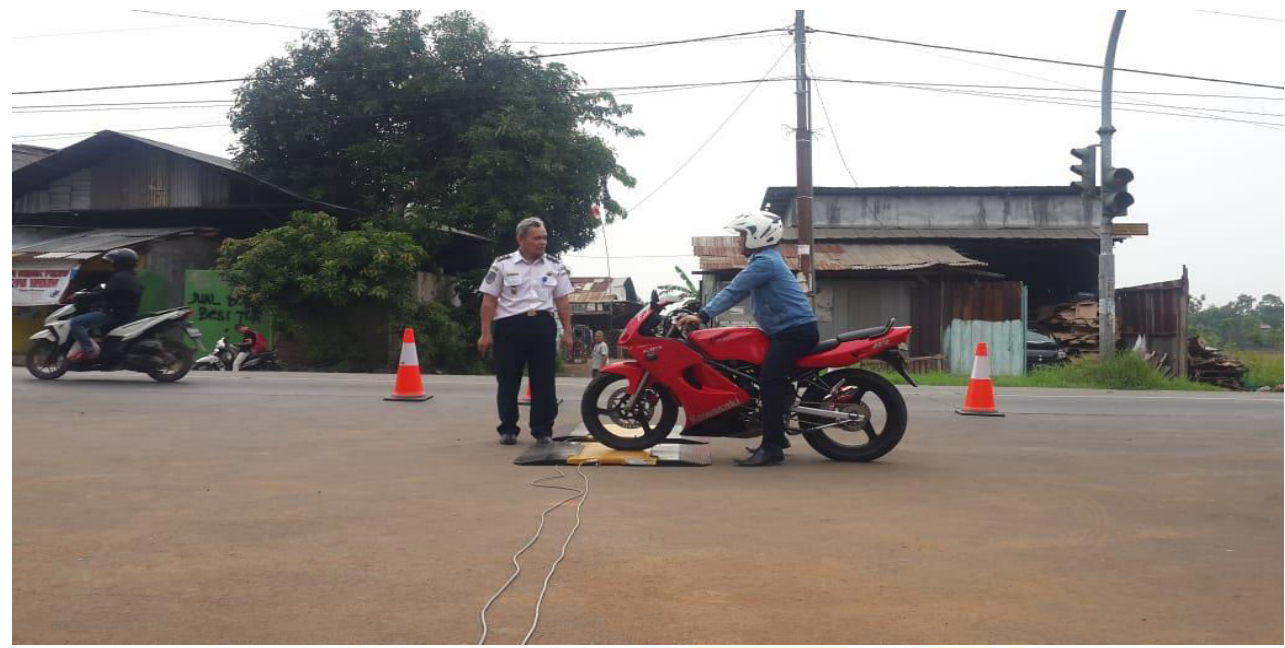
Roda Depan
$=240 \mathrm{Kg}$
Roda Belakang
$=250 \mathrm{Kg}$.
Total
$=490 \mathrm{Kg}$. 


\section{ANALISIS DAN PEMBAHASAN}

\section{Lokasi Penelitian}

Penelitian ini dilakukan di area Underpass Pasar Tambun Bekasi dengan menggunakan alat Weight In Motion (WIM)

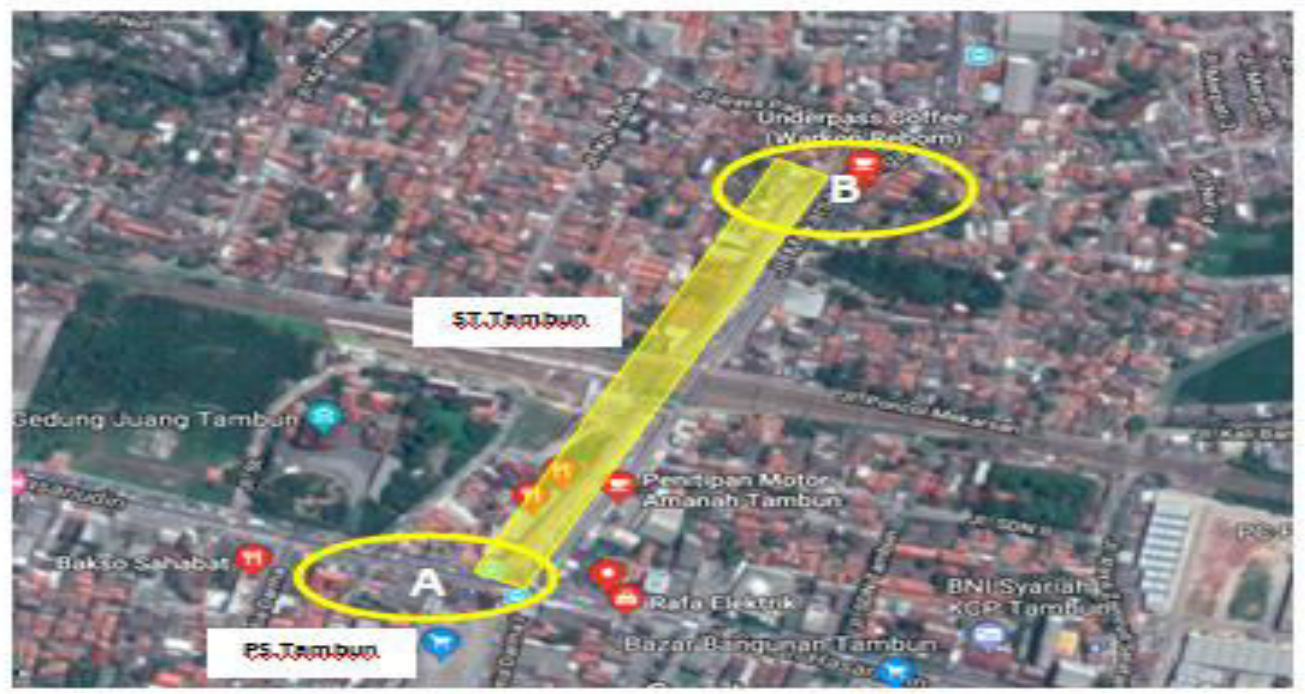

Gambar : Tata Guna Lahan Lokasi Penelitian

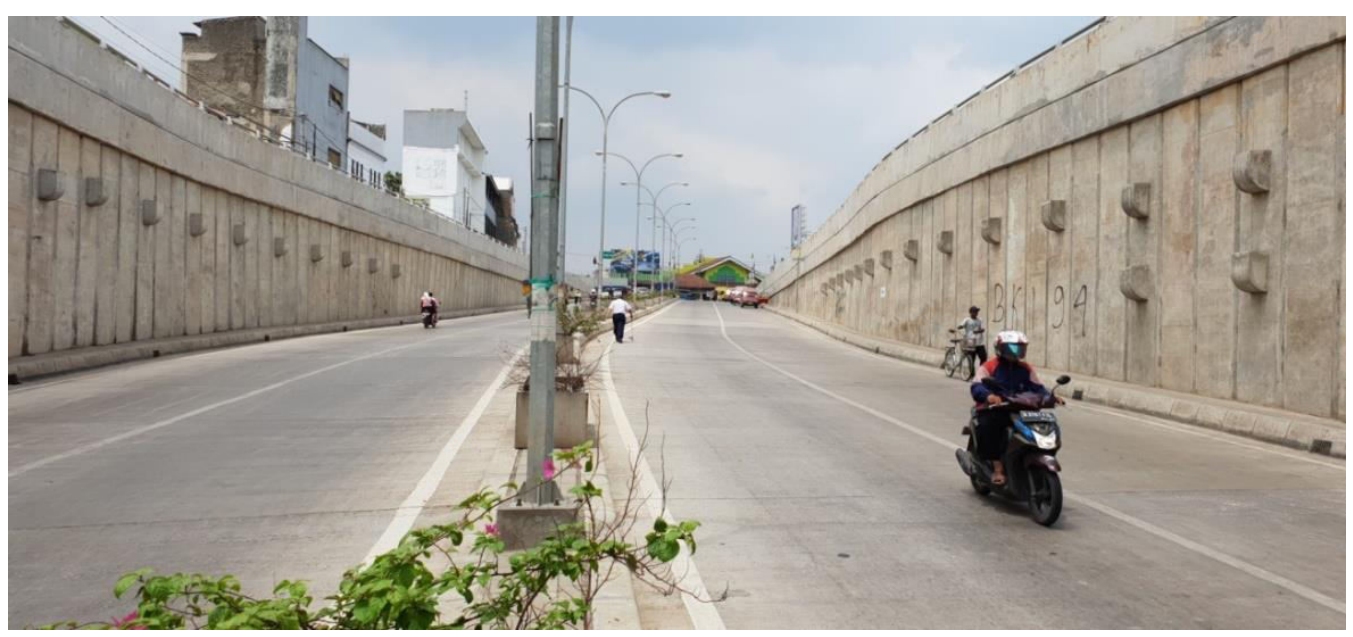

Gambar : Underpass Pasar Tambun Bekasi 


\section{Analisa Kecepatan Kendaraan}

Rumus dasar dari kecepatan dapat dinyatakan sebagai berikut:

$$
V=d / t
$$

Dimana :

$$
\begin{array}{ll}
\mathrm{V} & =\text { Kecepatan }(\mathrm{km} / \mathrm{jam}) \\
\mathrm{d} & =\text { Jarak yang ditempuh kendaraan }(\mathrm{km}) \\
\mathrm{t} & =\text { Waktu tempuh kendaraan }(\mathrm{jam})
\end{array}
$$

Berdasarkan hasil pengamatan di underpass Tambun, di diperoleh kecepatan berdasarkan jenis kendaraan, dapat dilihat pada Tabel 4.2 dan Tabel 4.3

Tabel Kecepatan Kendaraan Arah Pasar Tambun - Tambelang.

\begin{tabular}{|c|c|c|c|c|}
\hline \multirow{2}{*}{$\begin{array}{c}\text { Kecepatan } \\
\text { Rata-rata } \\
(\text { Km/jam) }\end{array}$} & \multicolumn{4}{|c|}{ Jenis Kendaraan } \\
\cline { 2 - 5 } & Motor & $\begin{array}{c}\text { Mobil } \\
\text { Penumpang }\end{array}$ & \multicolumn{2}{|c|}{ Angkutan Barang } \\
\cline { 2 - 5 } & 21.43 & 22.50 & 31.50 & 23.00 \\
\hline
\end{tabular}

\subsection{Analisa Volume kendaraan}

Dari hasil survai Traffic Counting (TC) yang telah dilakukan diperoleh data jumlah kendaraan tersibuk selama satu jam pada jam sibuk pagi, siang dan sore, berikut adalah data survai Traffic Counting pada ruas J1 Raya Mangun Jaya. 
Tabel :Volume Kendaraan Tiap Jam Sibuk pada ruas Jl. Raya Mangun Jaya.

Arah : $\quad$ Pasar Tambun

Arah : Masuk Underpass

\begin{tabular}{|c|c|c|c|c|c|c|c|c|c|c|c|c|}
\hline \multirow[t]{2}{*}{ Pagi } & \multicolumn{2}{|c|}{$\begin{array}{c}\text { Kendaraan } \\
\text { Ringan }\end{array}$} & \multicolumn{2}{|c|}{$\begin{array}{c}\text { Kendaraan } \\
\text { Berat }\end{array}$} & \multicolumn{2}{|c|}{$\begin{array}{l}\text { Sepeda } \\
\text { Motor }\end{array}$} & \multicolumn{2}{|c|}{$\begin{array}{c}\text { Kendaraan } \\
\text { Ringan }\end{array}$} & \multicolumn{2}{|c|}{$\begin{array}{c}\text { Kendaraan } \\
\text { Berat }\end{array}$} & \multicolumn{2}{|c|}{$\begin{array}{l}\text { Sepeda } \\
\text { Motor }\end{array}$} \\
\hline & Kend & smp & Kend & smp & Kend & $\mathrm{smp}$ & Kend & smp & Kend & smp & Kend & smp \\
\hline & 211 & 211 & 8 & 10,4 & 485 & 97,0 & 84 & 84 & 8 & 10,9 & 326 & 65,2 \\
\hline & 198 & 198 & 11 & 14,56 & 584 & 116,8 & 94 & 94 & 22 & 29,1 & 342 & 68,3 \\
\hline & 170 & 170 & 11 & 14,56 & 491 & 98,2 & 52 & 52 & 13 & 16,4 & 248 & 49,6 \\
\hline & 142 & 142 & 13 & 16,64 & 395 & 79,0 & 39 & 39 & 11 & 14,6 & 169 & 33,9 \\
\hline & 722 & 722 & 43 & 56,16 & 1955 & 391,0 & 269 & 269 & 55 & 71,0 & 1085 & 217,0 \\
\hline \multirow[t]{2}{*}{ Total } & 211 & 211 & 8 & 10,4 & 485 & 97,0 & 84 & 84 & 8 & 10,9 & 326 & 65,2 \\
\hline & \multicolumn{6}{|c|}{1168,8} & \multicolumn{6}{|c|}{556,8} \\
\hline \multirow[t]{2}{*}{ Siang } & \multicolumn{2}{|c|}{$\begin{array}{c}\text { Kendaraan } \\
\text { Ringan }\end{array}$} & \multicolumn{2}{|c|}{$\begin{array}{c}\text { Kendaraan } \\
\text { Berat }\end{array}$} & \multicolumn{2}{|c|}{$\begin{array}{l}\text { Sepeda } \\
\text { Motor }\end{array}$} & \multicolumn{2}{|c|}{$\begin{array}{c}\text { Kendaraan } \\
\text { Ringan }\end{array}$} & \multicolumn{2}{|c|}{$\begin{array}{c}\text { Kendaraan } \\
\text { Berat }\end{array}$} & \multicolumn{2}{|c|}{$\begin{array}{l}\text { Sepeda } \\
\text { Motor }\end{array}$} \\
\hline & Kend & $\mathrm{smp}$ & Kend & smp & Kend & $\mathrm{smp}$ & Kend & smp & Kend & smp & Kend & smp \\
\hline & 132 & 132 & 5 & 6,5 & 303 & 60,6 & 60 & 60 & 6 & 7,8 & 233 & 46,6 \\
\hline & 124 & 124 & 7 & 9,1 & 365 & 73,0 & 67 & 67 & 16 & 20,8 & 244 & 48,8 \\
\hline & 106 & 106 & 7 & 9,1 & 307 & 61,4 & 37 & 37 & 9 & 11,7 & 177 & 35,4 \\
\hline & 89 & 89 & 8 & 10,4 & 247 & 49,4 & 28 & 28 & 8 & 10,4 & 121 & 24,2 \\
\hline Total & 451 & 451 & 27 & 35,1 & 1222 & 244,4 & 192 & 192 & 39 & 50,7 & 775 & 155,0 \\
\hline & & & 730,5 & & & & & & & & & \\
\hline
\end{tabular}

\begin{tabular}{|c|c|c|c|c|c|c|c|c|c|c|c|c|}
\hline \multirow[t]{2}{*}{ Sore } & \multicolumn{2}{|c|}{$\begin{array}{c}\text { Kendaraan } \\
\text { Ringan }\end{array}$} & \multicolumn{2}{|c|}{$\begin{array}{c}\text { Kendaraan } \\
\text { Berat }\end{array}$} & \multicolumn{2}{|c|}{$\begin{array}{l}\text { Sepeda } \\
\text { Motor }\end{array}$} & \multicolumn{2}{|c|}{$\begin{array}{c}\text { Kendaraan } \\
\text { Ringan }\end{array}$} & \multicolumn{2}{|c|}{$\begin{array}{c}\text { Kendaraan } \\
\text { Berat }\end{array}$} & \multicolumn{2}{|c|}{$\begin{array}{l}\text { Sepeda } \\
\text { Motor }\end{array}$} \\
\hline & Kend & smp & Kend & smp & Kend & $\operatorname{smp}$ & Kend & smp & Kend & smp & Kend & smp \\
\hline & 185 & 185 & 7 & 9,1 & 424 & 84,8 & 96 & 96 & 10 & 12,5 & 373 & 74,6 \\
\hline & 174 & 174 & 10 & 12,74 & 511 & 102,2 & 107 & 107 & 26 & 33,3 & 390 & 78,1 \\
\hline & 148 & 148 & 10 & 12,74 & 430 & 86,0 & 59 & 59 & 14 & 18,7 & 283 & 56,6 \\
\hline & 125 & 125 & 11 & 14,56 & 346 & 69,2 & 45 & 45 & 13 & 16,6 & 194 & 38,7 \\
\hline Total & 631 & 631 & 38 & 49,14 & 1711 & 3422 & 307 & 307 & 62 & 81,1 & 1240 & 248,0 \\
\hline
\end{tabular}




\section{PENUTUP}

Kesimpulan.

Dari hasil pembahasan diatas dapat disimpulkan pebelitian dari pengaruh beban lalu

\section{lintas terhadap umur perkerasan rigid sebagai berikut :}

a. Kecepatan Kendaraan rata-rata :

1) Arah Pasar Tambun menuju Tambelang, untuk jenis kendaraan :
a) Motor
: $21,43 \mathrm{~km} / \mathrm{jam}$.
b) Mobil Penumpang
: $22,50 \mathrm{~km} / \mathrm{jam}$.
c) Box Angkutan Barang
: $31,50 \mathrm{~km} / \mathrm{jam}$.
d) Truk Angkutan Barang
: $23,00 \mathrm{~km} / \mathrm{jam}$.

2) Arah Tambelang menuju Pasar Tambun, untuk jenis kendaraan :
a) Motor
: $25,81 \mathrm{~km} / \mathrm{jam}$.
b) Mobil Penumpang
: $24,34 \mathrm{~km} / \mathrm{jam}$.
c) Box Angkutan Barang
: $23,70 \mathrm{~km} / \mathrm{jam}$.
d) Truk Angkutan Barang
: $23,94 \mathrm{~km} / \mathrm{jam}$.

b. Total Volume Kendaraan Ringan, Berat dan Sepeda Motor :

1) pada pagi hari :
a) Untuk arah Pasar Tambun
$1168,8 \mathrm{smp}$.
b) Umtuk arah masuk Underpass
$556,8 \mathrm{smp}$.

2) pada siang hari :
a) Untuk arah Pasar Tambun
$730,5 \mathrm{smp}$.
b) Umtuk arah masuk Underpass : $\quad 397,7 \mathrm{smp}$.

3) pada sore hari :
a) Untuk arah Pasar Tambun
1022,7 smp.
b) Umtuk arah masuk Underpass : $\quad 636,3 \mathrm{smp}$

c. Total Axle Load Rata-rata untuk Moda :
1) Truk Sedang
: $2.390 \mathrm{~kg}$.
2) Truk Kecil/ Pick Up
: $1.780 \mathrm{~kg}$.
3) Mobil Penumpang : $790 \mathrm{~kg}$.
4) Mobil Penumpang Umum : $1.480 \mathrm{~kg}$.
5) Mobil Box : $690 \mathrm{~kg}$.
6) Sepeda Motor : : $490 \mathrm{~kg}$. 
d. Dari hasil peninjauan lokasi penelitian diketahui bahwa Underpass Pasar Tambun dibangun dengan konstruksi Perkerasan Kaku (Rigid Pavement) dengan dengan kemiringan slope alinyemen memanjang sekitar $3 \%$.

e. Kondisi permukaan konstruksi perkerasan kaku di jalanUnderpass Pasar Tambun secara visual belum terlihat adanya kerusakan yang signifikan, sehingga dari hasil pengukuran dan perhitungan kecepatan kendaraan, volume dan beban kendaraan eksisting yang melintas di jalan Underpass Pasar Tambun, diperkirakan bahwa umur rencana perkerasan kaku jalan tersebut dapat tercapai sampai nilai pelayanan dari jalan tersebut berakhir (jalan rusak tidak dapat dimanfaatkan).

Saran

a. Untuk supaya umur rencana yang diperhitungkan tercapai pada pembangunan perkerasan rigid di Jalan Underpass Pasar Tambun, maka perlu dilakukan pengawasan dan pembatasan bagi kendaraan pengangkut muatan yang belebihan dari ketentuan yang berlaku.

b. Perlu dilakukan pemeliharaan perkerasam rigid di jalan Underpass Pasar Tambun secara periodik dari kondisi lingkungan yang berpotensi mengurangi daya dukung perkerasan rigid tersebut, sehingga umur rencana yang diharapkan dapat tercapai.

c. Perlu dilakukan penelitian lanjutan untuk mengukur perkerasan kaku di jalan Underpass Pasar Tambun habis nilai pelayanannya (jalan rusak). 


\section{DAFTAR PUSTAKA}

Ahmad M, 2006, Manajemen Lalu Lintas Perkotaan, Beta Offset, Yogyakarta

Arends BPM \& Berenschot H,1980, Motor Bensin, translate of Benzinemotoren, Erlangga, Jakarta

Morlok EK., 1995, Pengantar Teknik dan Perencanaan Transportasi, Erlangga, Jakarta.

Muziansyah D, Sulistyorini R, dan Sebayang S, 2015, Model Emisi Gas Buangan Kendaraan Bermotor akibat Aktivitas Transportasi ( Studi kasus : Terminal Pasar Bawah Ramayana Kota Bandar Lampung), JRSDD Edisi Maret 2015,vol.3 No.1 Hal : 57 (ISSN : 2303-0011)

Novita S, Sumantri W P and Budiharso H, 2015, Level of Gas Emissions of Passenger Car On Climb Road Segment, International Symposium For Sustainable Landscape Development tanggal 14 November 2017 IPB, Bogor

Olivier G.J., et al, 2016, Trends In Global $\mathrm{CO}_{2}$ Emissions 2016 Report, PBL Netherlands Environmental Agency, Netherlands, http://edgar.jrc.ec.europa.eu/news_docs/jrc-2016-trends-in-global-co2-emissions2016-report-103425.pdf

Tarigan A, 2009, Estimasi Emisi Kendaraan Bermotor di beberapa Ruas Jalan Kota Medan, Tesis Universitas Sumatera Utara, Medan

Peraturan Menteri Negara Lingkungan Hidup Nomor 12 tahun 2010 tentang Pelaksanaan Pengendalian Pencemaran Udara di Daerah ,2014, Greenship untuk Bangunan Baru versi 1.2, Green Building council Indonesia, Jakarta

Ahmad M, 2006, Manajemen Lalu Lintas Perkotaan, Beta Offset, Yogyakarta

Direktorat Bina Sistem Lalu Lintas dan Angkutan Kota Direktorat Jenderal Perhubungan Darat,1999, Rekayasa Lalu Lintas, Direktorat Bina Sistem Lalu Lintas dan Angkutan Kota Direktorat Jenderal Perhubungan, Jakarta 